\title{
OPTIMASI PEMILIHAN LOKASI FASILITAS PENGOLAHAN LIMBAH ELEKTRONIK (E-WASTE) DI INDONESIA DENGAN MODEL ELECTRE III
}

\author{
Pertiwi Andarani $^{*}$, Wiwik Budiawan*) \\ Program Studi Teknik Lingkungan ${ }^{1}$, Program Studi Teknik Industri ${ }^{2}$ \\ Fakultas Teknik UNDIP, Jl. Prof H. Sudarto SH Tembalang Semarang
}

\begin{abstract}
Abstrak
Limbah elektronik adalah masalah yang muncul di Indonesia karena mengandung bahan yang berpotensi berbahaya. Dalam rangka menciptakan manajemen yang ramah lingkungan dari limbah elektronik, fasilitas yang memadai diperlukan. Tujuan dari penelitian ini adalah untuk memilih lokasi yang optimal untuk mengembangkan fasilitas pengolahan limbah elektronik (FLPE). Pemilihan lokasi yang optimal dilakukan dengan menggunakan metode model ELECTRE III. ELECTRE adalah keluarga metode analisis keputusan multi-kriteria yang berasal di Eropa. Kriteria yang dipilih untuk analisis ini adalah penduduk setempat, penduduk yang dilayani, persentase belanja bulanan, harga rata-rata rumah tangga per unit, populasi pengangguran, status finansial dari penduduk lokal, jarak dari fasilitas yang telah ada, dan jarak dari pelabuhan terdekat. ELECTRE III membutuhkan penentuan tiga ambang batas, yaitu ambang kelalaian (q), ambang batas preferensi (p), dan ambang veto (v) dalam upaya untuk lebih beradaptasi dengan ketidakpastian. Bobot masing-masing kriteria yang ditentukan sesuai dengan kepentingan relatif terhadap kriteria lain. Lokasi optimal untuk FPLE adalah Provinsi Banten berdasarkan model ELECTRE III.
\end{abstract}

Kata Kunci: limbah elektronik, fasilitas, optimasi, ELECTRE

\begin{abstract}
E-waste is an emerging issue in Indonesia due to its potentially hazardous content and some precious metal. In order to create an environmentally sound management of e-waste, a facility is necessary. The objectives of this study are to to select the optimal location of e-waste dismantling and sorting facility (DSF/FLPE). The optimal location selection was conducted using the method of ELECTRE III model. ELECTRE is a family of multi-criteria decision analysis methods that originated in Europe. The criteria chosen for this analysis are local population, population served, the percentage of monthly expenditure, average household price per unit, unemployed population, financial status of the local population, distance from existing facilities, and distance from the nearest port. ELECTRE III requires the determination of three thresholds, namely threshold of negligence $(q)$, threshold of preference ( $p)$, and the veto threshold $(v)$ in the effort to better adapt to uncertainties. The weight of each criterion was determined according to its importance relative to other criteria. The optimal location for e-waste DSF is Banten Province based on ELECTRE III model.
\end{abstract}

Keywords: e-waste, facility, optimization, ELECTRE

\section{Pendahuluan}

Limbah elektronik (e-waste) merupakan salah satu jenis limbah yang seharusnya memiliki perlakuan khusus dan dapat dipisahkan dari sistem manajemen sampah perkotaan. Akan tetapi, belum ada undang-undang atau peraturan yang mengatur secara spesifik tentang pengelolaan limbah e-waste ini di Indonesia. Padahal limbah elektronik memiliki

\footnotetext{
${ }^{*}$ Penulis Korespondensi.

email: andarani@gmail.com, wiwikbudiawan@undip.ac.id
}

potensi bahaya apabila dikelola secara sembarangan dan di sisi lain, memiliki potensi ekonomi apabila material-material atau logam berharga dapat didaur ulang kembali (recycle).

Secara formal, belum ada industri yang mendaur ulang limbah-limbah elektronik di Indonesia. Limbah elektronik dikelola sebagian besar oleh sektor informal. Di Indonesia, umumnya sulit untuk menemukan e-waste, baik dalam bentuk utuh atau komponen, dibuang di TPA resmi atau tempat pembuangan sampah (Widyarsana, 2011). Kesulitan ekonomi memaksa ribuan orang miskin untuk mencari penghidupan dari mengais limbah 
elektronik, sehingga mendapatkan paparan terhadap bahaya kesehatan. Barang elektronik yang sudah tidak dipakai dan tidak diinginkan dibuang ke tempat pembuangan bersama dengan limbah lainnya, kemudian diambil oleh pemulung untuk dijual kembali di toko service maupun penadah. Komponen atau bagian yang tidak terjual kemudian dibuang sembarangan, sehingga berpotensi mencemari lingkungan dan badan air.

Namun demikian, terdapat industri di Indonesia yang mendaur ulang peralatan elektronik yang berasal dari kegiatan bisnis atau impor (diimpor sebagai metal scrap). Potensi bisnis daur ulang limbah dapat dikatakan feasible apabila didukung oleh mekanisme pendanaan tambahan (Andarani dan Goto, 2012). Agar dapat mengelola e-waste secara efisien, infrastruktur yang cukup harus dibangun. Minimal, infrastruktur tersebut terdiri dari pusat pengumpulan dan sarana daur ulang e-waste. Pusat pengumpulan e-waste dapat dibuat secara regional dan kemudian memusat menuju ke sarana daur ulang e-waste. Mengingat Indonesia memiliki wilayah yang luas maka penting untuk dapat memilih lokasi optimal untuk membangun sarana tersebut.

Indonesia merupakan negara kepulauan yang terdiri dari sekitar 17.508 pulau (ASEM, 2010) dan memiliki 33 provinsi dengan penduduk lebih dari 238 juta orang sehingga menempati urutan keempat dalam jumlah penduduk dunia (CEIC, 2011). Memilih lokasi yang optimal untuk fasilitas pengolahan limbah elektronik (FPLE) bukanlah tugas yang mudah. Pengambilan keputusan pada lokasi yang optimal untuk pengembangan FPLE di Indonesia merupakan masalah yang sangat penting, baik untuk kelangsungan hidup investasi itu sendiri dan efisiensi skema pengumpulan limbah elektronik.

Tujuan penelitian ini adalah untuk mengidentifikasi lokasi sarana dan fasilitas untuk pengelolaan limbah elektronik di Indonesia. Dengan diperoleh hasil yang optimal, diharapkan industri tersebut dapat berlangsung berkelanjutan dengan tetap memperhatikan sisi manajemen lingkungan.

\section{Metodologi}

Dalam rangka untuk memilih lokasi yang optimal untuk membangun fasilitas pengolahan limbah elektronik (FPLE), maka perlu mempertimbangkan banyak kriteria yang terlibat dalam proses pengambilan keputusan, meskipun tidak jarang bahwa antar kriteria terkadang bertentangan satu sama lain. Yang paling penting, pembuat keputusan perlu mempertimbangkan: (i) pengembangan dan pengoperasian biaya, (ii) keberadaan semua infrastruktur dasar yang diperlukan (jaringan jalan, tenaga kerja yang tersedia, dll), (iii) jarak dari FPLE yang ada, (iv) Target populasi, dan (v) penerimaan sosial (Achillas, dkk, 2010).
Pertama-tama, pembuat keputusan harus melakukan survei menyeluruh di lokasi-lokasi alternatif yang cocok untuk pengembangan FPLE. Kemudian, beberapa kriteria keputusan tertentu diperlukan untuk memilih lokasi yang optimal, bersama-sama dengan signifikansi relatif mereka (faktor bobot). Langkah ini memungkinkan penggabungan tujuan strategis yang spesifik sesuai dengan filosofi pemangku kepentingan dalam proses pengambilan keputusan (Achillas, dkk, 2010). Jumlah kriteria untuk proses pengambilan keputusan tergantung pada pengambil keputusan. Setelah kriteria dan bobot didefinisikan dengan jelas, semua data yang diperlukan harus dikumpulkan serta kuantifikasi nilai-nilai kualitatif. Hal ini merupakan tahap yang paling banyak membutuhkan waktu dan sumber daya dalam proses pengambilan keputusan. Karena berbagai unit diterapkan pada nilai masingmasing kriteria, perlu untuk menormalkan nilai tersebut ke dalam nilai yang sebanding antara setiap kriteria. Nilai-nilai kuantitatif dari semua kriteria $\mathrm{j}$ untuk semua lokasi alternatif A normal pada skala 0100, sebagai berikut

$$
N_{j}(A)=\frac{g_{j}(A)-g_{j}^{\min }}{g_{j}^{\max }-g_{j}^{\min }} \cdot 100
$$

Dimana $g_{j}$ adalah nilai dari kriteria j untuk alternatif $\mathrm{A}, g_{j}^{m m}$ adalah nilai minimum kriteria $\mathrm{j}$, $g_{I}^{\text {man }}$ adalah nilai maksimum kriteria j.

Evaluasi multikriteria lokasi alternatif $\left(\mathrm{A}_{1}, \mathrm{~A}_{2}\right.$, $\left.A_{3}, \ldots\right)$ untuk lokasi FPLE pada atribut dilakukan seobjektif mungkin. Proses menggabungkan atribut ke dalam kriteria melibatkan tingkat pertama subjektivitas. Pada tingkat ini, adalah penting bahwa kriteria dan cara mereka diuraikan diterima oleh berbagai pengambil keputusan; seperti pemerintah, produsen, distributor, pengecer, dan bahkan konsumen / masyarakat. Namun, dalam penelitian ini, seperangkat kriteria $\left(\mathrm{C}_{1}, \mathrm{C}_{2}, \mathrm{C}_{3}, \ldots\right)$ telah dipilih sesuai dengan studi Achillas, dkk (2010) dan dimodifikasi berdasarkan data yang tersedia di Indonesia. Tingkat subjektivitas, diperhitungkan dalam tahap selanjutnya dari pendekatan, berkaitan dengan informasi preferensi yang mencerminkan, misalnya, kepentingan relatif dari setiap kriteria. Di sini, setiap pengambil keputusan memiliki kesempatan untuk menyatakan pandangannya sendiri sehingga untuk menghadapi penilaian pada sistem yang berbeda.

Pendekatan yang digunakan dalam rangka analisis ini menggunakan skema peringkat berdasarkan konsep ELECTRE III. ELECTRE adalah keluarga metode analisis keputusan multikriteria yang berasal dari Eropa pada pertengahan 1960-an. Akronim ELECTRE merupakan singkatan dari ELimination Et Choix Traduisant la REalité (ELimination and Choice Expressing REality). ELECTRE III menjadi metode yang paling umum digunakan untuk pengambilan keputusan pengelolaan 
sampah dalam literatur. Salminen, dkk (1998) dalam Achillas, dkk, (2010) membandingkan tiga metode multikriteria dalam konteks masalah lingkungan dan menyimpulkan bahwa ELECTRE III adalah yang paling cocok. ELECTRE pada awalnya dikembangkan oleh Roy pada pertengahan. 1960 untuk menggabungkan sifat kabur (tidak tepat dan tidak pasti) dalam pengambilan keputusan, dengan menggunakan ambang batas indifferen (indifference) dan preferensi (preference). Ciri selanjutnya dari ELECTRE, yang membedakannya dari banyak beberapa metode solusi kriteria, adalah bahwa pada dasarnya tidak ada kompensasi. Ini berarti, khususnya, nilai yang sangat buruk pada kriteria tidak dapat dikompensasikan dengan nilai yang baik pada kriteria lainnya.

\section{Pemodelan}

ELECTRE III membutuhkan penentuan tiga ambang batas, yaitu ambang kelalaian/negligence $(q)$, ambang preferensi/preference $(p)$, dan ambang veto (v) dalam upaya untuk lebih beradaptasi dengan ketidakpastian tersebut (Roy dan Bouyssou, 1993 dalam Achillas, dkk, 2010). Dengan menggunakan ambang batas, metode ELECTRE berusaha untuk membangun hubungan outranking, S. Untuk menyatakan $A_{1} \mathbf{S} A_{2}$ berarti " $A_{1}$ setidaknya sama baiknya dengan $A_{2}$ " atau " $A_{1}$ tidak lebih buruk dari $A_{2}$ ". Setiap pasangan alternatif $A_{1}$ dan $A_{2}$ kemudian diuji untuk memeriksa apakah pernyataan $A_{1} \mathbf{S} A_{2}$ valid atau tidak. Tes untuk menerima pernyataan $A_{1} \mathbf{S}$ $A_{2}$ diimplementasikan menggunakan dua prinsip (Buchanan, dkk, 1999):

a. Sebuah kesesuaian (concordance) $\left(c_{j}\right)$ prinsip yang mensyaratkan bahwa mayoritas kriteria, setelah mempertimbangkan kepentingan relatif mereka, adalah mendukung pernyataan - prinsip mayoritas, dan

b. Sebuah non-kejanggalan (discordance) $\left(d_{j}\right)$ prinsip yang mensyaratkan bahwa dalam minoritas kriteria yang tidak mendukung pernyataan, tidak satupun dari mereka sangat menentang pernyataan - prinsip minoritas.

Untuk membandingkan sepasang alternatif $\left(A_{1}\right.$, $A_{2}$ ) untuk masing-masing kriteria, pernyataan " $A_{l} \mathbf{S}$ $A_{2}$ "dievaluasi dengan bantuan pseudo-kriteria. Pseudo-kriteria terdiri dari dua batas, yaitu indiferen $\left(q_{j}\right)$ dan preferensi $\left(p_{j}\right)$, sebagai berikut:

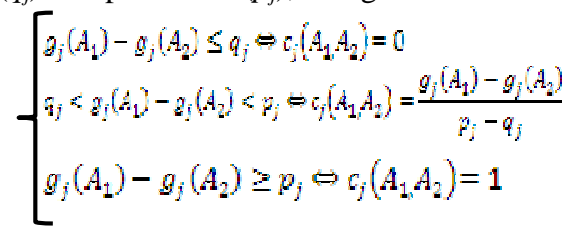

Sebuah indeks kesesuaian global $C_{A_{1} A_{2}}$ untuk setiap pasangan alternatif $\left(A_{1}, A_{2}\right)$ dihitung dengan indeks kesesuaian $c_{j}\left(A_{1}, A_{2}\right)$ setiap kriteria $j$ :
$C_{A_{1} A_{1}}=\frac{\sum_{j=1}^{n} w_{j} \times c_{j}\left(A_{1}, A_{2}\right)}{\sum_{j=1}^{n} w_{j}}$

dimana $w_{j}$ adalah bobot kriteria $j$.

Sementara itu, indeks kejanggalan $\left(d_{j}\right)$ dievaluasi dengan bantuan pseudo-kriteria dengan ambang veto $\left(v_{p}\right)$, yang merupakan selisih maksimum $g_{j}\left(A_{1}\right)-g_{j}\left(A_{2}\right)$ yang dapat diterima untuk tidak menolak pernyataan " $\mathrm{A}_{1} \mathbf{S} \mathrm{A}_{2}$ ", yang berlaku berikut ini:

$$
\left\{\begin{array}{l}
g_{j}\left(A_{1}\right)-g_{j}\left(A_{2}\right) \leq p_{j} \Leftrightarrow d_{j}\left(A_{1}, A_{2}\right)=0 \\
v_{j}<g_{j}\left(A_{1}\right)-g_{j}\left(A_{2}\right)<q_{j} \Leftrightarrow d_{j}\left(A_{1}, A_{2}\right)=\frac{g_{j}\left(A_{1}\right)-g_{j}\left(A_{2}\right)-p_{j}}{v_{j}-p_{j}} \\
g_{j}\left(A_{1}\right)-g_{j}\left(A_{2}\right) \geq v_{j} \Leftrightarrow d_{j}\left(A_{1} A_{2}\right)=1
\end{array}\right.
$$

Untuk setiap pasangan $\left(A_{1}, A_{2}\right) \in \mathrm{A}$, di sana sekarang ada ukuran kesesuaian dan ketidaksesuaian. Langkah terakhir dalam tahap pembentukan model adalah untuk menggabungkan kedua ukuran ini untuk menghasilkan ukuran tingkat outranking; yaitu, matriks kredibilitas, yang menilai kekuatan pernyataan bahwa " $A_{1}$ setidaknya sama baiknya dengan $A_{2}$ ". Indeks kredibilitas, $\delta_{A_{1} A_{2}}$, dari pernyataan " $\mathrm{A}_{1} \mathbf{S} \mathrm{A}_{2}$ " dalam A didefinisikan sebagai berikut:

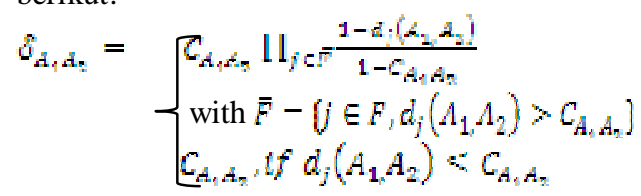

Formula ini mengasumsikan bahwa jika kekuatan kesesuaian melebihi ketidaksesuaian, maka nilai kesesuaian tidak boleh diubah. Jika tidak, kredibilitas pernyataan bahwa " $\mathrm{A}_{1} \quad \mathbf{S} \mathrm{A}_{2}$ " harus kembali dievaluasi dan dimodifikasi $C_{A_{1} A_{\mathrm{I}}}$ sesuai dengan persamaan indeks kredibilitas $\left(\delta_{A_{1} A_{n}}\right)$.

Hal ini menyimpulkan pembangunan model outranking. Algoritma peringkat ELECTRE III menggunakan matriks kredibilitas untuk membangun dua peringkat dengan menggunakan distilasi menurun (descending) dan naik (ascending): distilasi menurun pada awalnya memilih alternatif terbaik kemudian mengakhiri proses dengan yang terburuk. Sebaliknya distilasi naik pertama memilih alternatif terburuk kemudian mengakhiri proses dengan yang terbaik. Oleh karena itu kedua urutan tersebut lengkap ditemukan di semua alternatif. Sebuah alternatif yang tak tertandingi kepada sekelompok orang lain akan diposisikan pada akhir grup ini didistilasi turun dan di atas dalam distilasi naik. Dalam penelitian ini, model ELECTRE III akan dijalankan oleh perangkat lunak LAMSADE (LAMSADE, 2009). Hanya alternatif terbaik dari solusi optimal yang akan dipilih sebagai lokasi FPLE. 


\section{Pengumpulan Data}

Seperti disebutkan sebelumnya, di Indonesia, belum ada FPLE limbah elektronik yang resmi ditetapkan. Fasilitas ini harus dibentuk sesuai dengan ketentuan spesifik tentang limbah elektronik yang kini sedang dipersiapkan oleh Kementerian Lingkungan Hidup. Menurut CIA (2009), Indonesia memiliki $1.811 .569 \mathrm{~km} 2$ dari luas lahan, dengan populasi 248.216.193 orang (estimasi Juli 2011). Indonesia terdiri dari 33 provinsi sejak tahun 1999 (Peraturan Menteri Dalam Negeri Nomor 66/2011 tentang Kode dan Data Administrasi Pemerintah Daerah). Dalam penelitian ini, semua 33 provinsi akan dianggap sebagai lokasi potensi DSF. Sejak tahun 1999, Indonesia telah memperluas provinsi yang dari 27 provinsi menjadi 33 provinsi, maka, beberapa data belum tersedia (seperti harga rumah, dll). Dalam kasus data tidak tersedia, data akan diambil dari provinsi versi lama tersebut. Peta provinsi di Indonesia dapat dilihat pada Gambar 1.

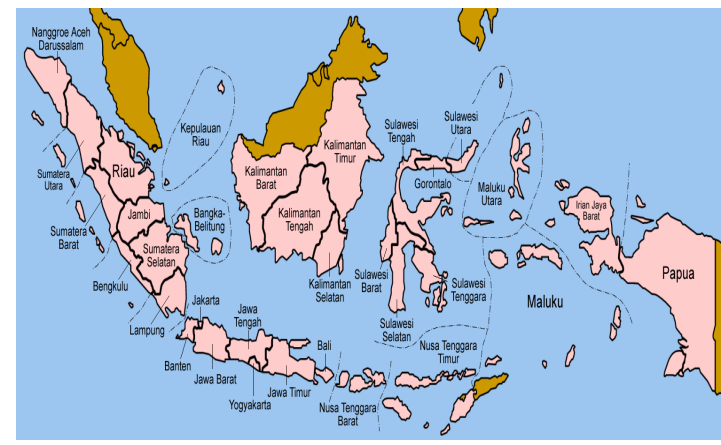

Gambar 1. Peta Provinsi di Indonesia

Sumber:

http://upload. wikimedia.org/wikipedia/commons/2/2b/Indonesia_provi nces_indonesian.png (Diakses: 14 December, 2014)

Dalam setiap penelitian mengenai lokasi, pertanyaan yang paling penting adalah mendefinisikan kriteria yang harus dipertimbangkan (Achillas, dkk, 2010). Menurut Achillas, dkk (2010), 9 kriteria harus dimasukkan dalam studi kasus menyediakan lokasi yang optimal untuk pengembangan dua pabrik pengolahan limbah elektronik di Yunani, seperti jumlah penduduk setempat; penduduk yang dilayani; jarak dari pabrik pengolahan yang ada; harga tanah; populasi pengangguran; fasilitas perhubungan darat; status ekonomi penduduk lokal; jarak dari ibukota daerah; dan jarak dari pelabuhan terdekat. Kriteria ini dipilih berdasarkan wawancara terhadap semua ahli di bidang tematik yang diteliti dan memahami pengetahuan tentang manajemen limbah elektronik di Yunani. Dalam kasus Indonesia, 8 kriteria telah dipilih untuk menjadi kriteria untuk memilih lokasi optimal FPLE, pada dasarnya kriteria tersebut diadaptasi dari studi Achillas, dkk (2010) dan disesuaikan dengan data yang tersedia di Indonesia. i. Penduduk setempat $\left(\mathrm{c}_{1}\right)$ sebagai estimasi jumlah timbulan limbah elektronik e-waste (karena data jumlah limbah elektronik tidak tersedia untuk setiap provinsi). Kriteria ini juga bisa menunjukkan peluang untuk memasarkan produk akhir FPLE ke pasar sekunder (daur ulang, eksportir, produsen, dll).

ii. Penduduk yang dilayani $\left(\mathrm{c}_{2}\right)$ dapat dianggap sebagai jumlah limbah elektronik yang dapat ditangani oleh FPLE.

iii. Persentase belanja bulanan per kapita (komoditas non-pangan) di daerah perkotaan $\left(c_{3}\right)$ sebagai indikator yang mendorong timbulan limbah elektronik. Sebagai persentase ini meningkat, kemungkinan memiliki produk elektronik juga meningkat.

iv. Harga rumah rata-rata per unit $\left(\mathrm{c}_{4}\right)$ dapat dianggap sebagai nilai harga tanah yang merupakan biaya investasi. Karena harga tanah masing-masing provinsi yang tidak tersedia secara resmi, kriteria ini harus cocok dengan biaya investasi di masing-masing provinsi di Indonesia. Jika nilai tanah tinggi, harga rumah akan tinggi juga.

v. Populasi pengangguran $\left(\mathrm{c}_{5}\right)$ sebagai indikator untuk tenaga kerja yang tersedia. DSF baru harus mampu menciptakan lapangan kerja. Selain itu, kriteria ini bisa menunjukkan penerimaan sosial untuk pengembangan fasilitas industri.

vi. Status finansial penduduk lokal $\left(\mathrm{c}_{6}\right)$ sebagai indikator lain untuk penerimaan sosial terhadap fasilitas tersebut, dinyatakan dalam istilah Produk Domestik Bruto per kapita.

vii. Jarak dari FPLE yang sudah ada $\left(\mathrm{C}_{7}\right)$ dapat merupakan daya saing dalam pengumpulan limbah elektronik. Di Indonesia, ada lokasi tidak resmi pengelolaan produk elektronik yang sudah usang, yaitu Pulau Batam (Kepulauan Riau) yang memiliki kewenangan khusus untuk mengimpor e-produk tanpa pajak dan daerah industri di Provinsi Jawa Timur di mana beberapa industri telah terikat pembebasan pajak impor hanya untuk produk yang akan diekspor.

viii. Jarak dari pelabuhan terdekat $\left(\mathrm{c}_{8}\right)$ mengindikasikan infrastruktur yang tersedia dan menentukan biaya transportasi.

Perhubungan darat termasuk kriteria karena semua provinsi sudah memiliki infrastruktur transportasi. Lokasi FPLE diasumsikan berada di 10 km dari ibukota provinsi, maka, kriteria jarak dari wilayah ibukota' juga dihilangkan, karena semua provinsi memiliki nilai yang sama. Tabel yang menunjukkan alternatif lokasi di setiap kriteria dapat dilihat pada Tabel 1, sedangkan Tabel 2 menunjukkan ambang batas dan faktor bobot masingmasing kriteria. 
Tabel 1. Performansi alternatif lokasi terhadap kriteria terpilih

\begin{tabular}{|c|c|c|c|c|c|c|c|c|c|}
\hline No & $\begin{array}{c}\text { Lokasi } \\
\text { Alternatif }\end{array}$ & $\begin{array}{c}c_{1}: \text { Penduduk } \\
\text { setempat } \\
(\text { populasi })^{\mathrm{a})}\end{array}$ & $\begin{array}{c}c_{2}: \text { Penduduk } \\
\text { dilayani } \\
(\text { orang })^{\text {a) }}\end{array}$ & $\begin{array}{c}\text { c }_{3}: \\
\text { Persentase } \\
\text { belanja } \\
\text { bulanan per } \\
\text { kapita }^{\text {a) }}\end{array}$ & $\begin{array}{l}c_{4} \text { : Harga } \\
\text { rumah rata- } \\
\text { rata per unit } \\
\text { a) }\end{array}$ & $\begin{array}{l}\text { c5: } \\
\text { Populasi } \\
\text { pengang } \\
\text { guran a) }^{\text {a }}\end{array}$ & $\begin{array}{c}\text { c}_{6}: \text { Status } \\
\text { Finansial } \\
\text { Penduduk } \\
\text { Setempat } \\
\left(\begin{array}{c}\text { PDB/kapita }) \\
\text { a) }\end{array}\right.\end{array}$ & $\begin{array}{c}\text { c }_{7}: \text { Jarak } \\
\text { dari } \\
\text { FPLE } \\
\text { yang ada } \\
(\mathbf{k m})\end{array}$ & $\begin{array}{c}\text { c8: Jarak } \\
\text { dari } \\
\text { pelabuhan } \\
(\mathbf{k m})\end{array}$ \\
\hline 1 & Aceh & $4,486,600$ & $17,471,700$ & $44.83 \%$ & $80,000,000$ & 8.60 & $16,215,900$ & 1138 & 5.5 \\
\hline 2 & Sumatera Utara & $12,985,100$ & $27,860,700$ & $51.61 \%$ & $58,000,000$ & 8.01 & $17,840,200$ & 688 & 21.8 \\
\hline 3 & Sumatera Barat & $4,846,000$ & $28,176,100$ & $48.80 \%$ & $56,000,000$ & 7.57 & $15,802,800$ & 488 & 5.4 \\
\hline 4 & Riau & $5,543,000$ & $28,148,400$ & $50.08 \%$ & $55,000,000$ & 7.21 & $60,210,800$ & 303 & 124.6 \\
\hline 5 & Kep. Riau & $1,685,700$ & $18,986,700$ & $53.21 \%$ & $60,000,000$ & 7.21 & $42,165,700$ & 52 & 1.5 \\
\hline 6 & $\begin{array}{l}\text { Jambi } \\
\text { Sumatera }\end{array}$ & $3,088,600$ & $25,546,100$ & $49.67 \%$ & $60,000,000$ & 4.45 & $15,107,100$ & 313 & $\begin{array}{c}93.8 \\
2.6\end{array}$ \\
\hline 7 & $\begin{array}{l}\text { Selatan } \\
\text { Kep.BangkaBeli } \\
\text { tung }\end{array}$ & $7,446,400$ & $22,753,200$ & $49.47 \%$ & $\begin{array}{c}57,000,000 \\
88,000,000^{b)}\end{array}$ & 6.55 & $18,906,900$ & 469 & 14.2 \\
\hline 9 & Bengkulu & $1,713,400$ & $25,913,500$ & $50.74 \%$ & $57,000,000$ & 4.06 & $9,318,200$ & 606 & 13.6 \\
\hline 10 & Lampung & $7,596,100$ & $80,382,300$ & $54.68 \%$ & $66,000,000$ & 5.95 & $11,789,000$ & 769 & 6.2 \\
\hline 11 & Jakarta & $9,588,200$ & $155,604,100$ & $61.86 \%$ & $119,000,000$ & 11.32 & $82,079,900$ & 656 & 13.8 \\
\hline 12 & Jawa Barat & $43,021,800$ & $145,382,200$ & $54.71 \%$ & $88,000,000$ & 10.57 & $15,710,900$ & 550 & 120.0 \\
\hline 13 & Banten & $10,644,000$ & $148,552,400$ & $56.54 \%$ & $88,000,000^{b)}$ & 14.13 & $13,598,300$ & 863 & 47.7 \\
\hline 14 & Jawa Tengah & $32,380,700$ & $155,604,100$ & $51.26 \%$ & $63,000,000$ & 6.86 & $11,957,700$ & 228 & 1.6 \\
\hline 15 & Yogyakarta & $3,452,400$ & $136,563,100$ & $57.47 \%$ & $55,000,000$ & 6.02 & $11,830,100$ & 218 & \\
\hline 16 & Jawa Timur & $37,476,000$ & $154,227,000$ & $51.57 \%$ & $77,000,000$ & 4.91 & $18,350,800$ & 73 & 10.3 \\
\hline 17 & $\begin{array}{l}\text { Bali } \\
\text { Nusa Tenggara }\end{array}$ & $3,891,400$ & $64,434,500$ & $58.10 \%$ & $95,000,000^{b)}$ & 3.57 & $16,214,900$ & 363 & $\begin{array}{r}6.8 \\
173\end{array}$ \\
\hline 18 & $\begin{array}{l}\text { Barat } \\
\text { Nusa Tenggara }\end{array}$ & $4,496,900$ & $29,435,200$ & $51.96 \%$ & $95,000,000^{b)}$ & 5.78 & $9,424,000$ & 463 & 2.4 \\
\hline 19 & $\begin{array}{l}\text { Timur } \\
\text { Kalimantan }\end{array}$ & $4,679,300$ & $20,100,000$ & $51.58 \%$ & $95,000,000^{b)}$ & 3.49 & $5,225,200$ & 1350 & 1.4 \\
\hline 20 & $\begin{array}{l}\text { Barat } \\
\text { Kalimantan }\end{array}$ & $4,393,200$ & $113,828,700$ & $50.83 \%$ & $59,000,000$ & 5.50 & $12,471,400$ & 631 & 2.7 \\
\hline 21 & $\begin{array}{l}\text { Tengah } \\
\text { Kalimantan }\end{array}$ & $2,202,600$ & $94,358,000$ & $46.19 \%$ & $55,000,000$ & 3.88 & $17,366,800$ & 669 & 3.5 \\
\hline 22 & $\begin{array}{l}\text { Selatan } \\
\text { Kalimantan }\end{array}$ & $3,626,100$ & $109,036,800$ & $54.57 \%$ & $67,000,000$ & 5.89 & $14,638,300$ & 575 & 1.4 \\
\hline 23 & Timur & $3,550,600$ & $70,268,700$ & $57.18 \%$ & $55,000,000$ & 10.45 & $88,920,100$ & 519 & \\
\hline 24 & Sulawesi Utara & $2,265,900$ & $7,890,600$ & $51.29 \%$ & $71,000,000$ & 10.48 & $14,379,500$ & 1838 & 40.4 \\
\hline 25 & $\begin{array}{l}\text { Gorontalo } \\
\text { Sulawesi }\end{array}$ & $1,038,600$ & $10,524,000$ & $49.38 \%$ & $57,000,000$ & 5.05 & $7,198,100$ & 1588 & $\begin{array}{c}4.0 \\
20.5\end{array}$ \\
\hline 26 & $\begin{array}{l}\text { Tengah } \\
\text { Sulawesi }\end{array}$ & $2,633,400$ & $19,679,600$ & $55.78 \%$ & $88,000,000^{b)}$ & 4.89 & $12,924,900$ & 1225 & 3.2 \\
\hline 27 & Selatan & $8,032,600$ & $28,115,200$ & $56.15 \%$ & $71,000,000$ & 7.99 & $12,632,500$ & 888 & \\
\hline 28 & $\begin{array}{l}\text { Sulawesi Barat } \\
\text { Sulawesi }\end{array}$ & $1,158,300$ & $27,389,300$ & $48.78 \%$ & $88,000,000^{b)}$ & 4.10 & $8,276,700$ & 963 & $\begin{array}{l}3.0 \\
1.4\end{array}$ \\
\hline 29 & Tenggara & $2,230,600$ & $20,142,800$ & $59.58 \%$ & $57,000,000$ & 4.77 & $12,111,600$ & 1288 & \\
\hline 30 & Maluku & $1,531,400$ & $20,903,700$ & $48.08 \%$ & $55,000,000$ & 9.13 & $5,277,400$ & 1810 & 0.8 \\
\hline 31 & Maluku Utara & $1,035,500$ & $11,496,300$ & $54.14 \%$ & $95,000,000^{b)}$ & 6.03 & $4,808,000$ & 1905 & 1.5 \\
\hline 32 & Papua & $2,852,000$ & $3,612,900$ & $48.25 \%$ & $100,000,000$ & 4.08 & $31,777,100$ & 3214 & 1.3 \\
\hline 33 & Papua Barat & 760,900 & $6,179,800$ & $48.98 \%$ & $145,000,000^{b)}$ & 7.77 & $19,557,100$ & 2524 & 0.7 \\
\hline
\end{tabular}

Sumber: a) BPS, 2010 ; b) Harga maksimum rumah rakyat (Peraturan Menteri Perumahan Rakyat No. 7/2012) 
Tabel 2. Faktor bobot dan ambang batas untuk pengembangan FPLE di Indonesia

\begin{tabular}{ccccccccc}
\hline & $\begin{array}{c}\mathbf{c}_{1}: \\
\text { Penduduk } \\
\text { setempat } \\
\text { (populasi) }\end{array}$ & $\begin{array}{c}\mathbf{c}_{2}: \\
\text { Penduduk } \\
\text { dilayani } \\
\text { (orang) }\end{array}$ & $\begin{array}{c}\text { Persentase } \\
\text { belanja } \\
\text { bulanan } \\
\text { per kapita }\end{array}$ & $\begin{array}{c}\mathbf{c}_{\mathbf{4}}: \text { Harga } \\
\text { rumah } \\
\text { rata-rata } \\
\text { per unit }\end{array}$ & $\begin{array}{c}\mathbf{c}_{5}: \text { Populasi } \\
\text { penganggur } \\
\text { an }\end{array}$ & $\begin{array}{c}\mathbf{c}_{6}: \text { Status } \\
\text { Finansial } \\
\text { Penduduk } \\
\text { Setempat } \\
\text { (PDB/kapita) }\end{array}$ & $\begin{array}{c}\mathbf{c}_{7}: \text { Jarak } \\
\text { dari FPLE } \\
\text { yang ada } \\
\text { (km) }\end{array}$ & $\begin{array}{c}\text { Jarak } \\
\text { dari } \\
\text { pelabuh } \\
\text { an (km) }\end{array}$ \\
\hline $\begin{array}{c}\text { Ambang } \\
\text { batas, } \\
\text { kelalaian, } \\
\text { Ambang } \\
\text { batas, }\end{array}$ & 200 & 500 & 1 & 1 & 1 & 1000 & 20 & 0 \\
$\begin{array}{c}\text { preferensi, } \\
\text { Veto, }\end{array}$ & 500 & 1000 & 2 & 2 & 2 & 2000 & 50 & 1 \\
Bobot & - & - & - & - & - & - & 50 & - \\
\hline
\end{tabular}

\section{Analisis Sensitivitas}

Sebagai langkah terakhir seleksi lokasi optimal untuk FPLE, analisis sensitivitas dilakukan karena nilai-nilai parameter dalam aplikasi berasal dari estimasi yang kadang-kadang lebih atau kurang dari kondisi nyata sehingga bisa jadi kurang dapat diandalkan (faktor bobot, ambang batas, kriteria nilai kualitatif, dll). Oleh karena itu, ambang batas masing-masing kriteria dimodifikasi $( \pm 5 \%, 10 \%$, $20 \%, 30 \%, 40 \%, 50 \%$ ) dari skenario kasus dasar sehingga dapat dipastikan apakah lokasi optimal masih dipilih dalam skenario modifikasi tersebut.

\section{Hasil Dan Pembahasan}

Setelah semua lokasi telah terdefinisi, diperoleh hasil perhitungan nilai normalisasi dari kriteria yang dipilih, faktor pembobotan, dan ambang batas, model matematika dari ELECTRE III untuk evaluasi lokasi optimal e-limbah pembongkaran dan fasilitas pemilahan di Indonesia. Model dijalankan dengan penggunaan LAMSADE (2009). Hasil model ini menunjukkan bahwa Provinsi Banten adalah lokasi yang paling optimal berdasarkan model ELECTRE III.

Situs optimal terbaik (Banten) dapat diintepretasikan sebagai akibat dari performansi lokasi tertentu yang sangat baik dalam kriteria "Populasi dilayani" (c2), posisi Provinsi Banten merupakan daerah yang strategis dan daerah sekitarnya juga memiliki sejumlah besar penduduk. Lokasi dekat ibukota Indonesia (Jakarta) yang berarti bahwa provinsi ini berkembang dengan baik. Pilihan terbaik berikutnya untuk pengembangan FPLE pertama adalah lokasi yang terletak di Jakarta atau Maluku atau Maluku Utara atau Papua. Jakarta jelas menunjukkan performa yang luar biasa karena kriteria "Penduduk lokal" ( $\left.\mathrm{c}_{1}\right)$ dan "Populasi dilayani" $\left(\mathrm{c}_{2}\right)$. Namun, pilihan lain seperti Jawa Barat, Jawa Tengah, Jawa Timur, yang juga memiliki sejumlah besar penduduk, dibatasi karena pusat daur ulang yang ada di Jawa Timur. Ambang batas veto telah diatur untuk membatasi model untuk tidak memilih lokasi dalam $50 \mathrm{~km}$ dari pusat daur ulang yang ada untuk menghindari sebanyak mungkin persaingan. Jika veto ambang batas tidak diatur dalam model, pilihan terbaik untuk lokasi DSF adalah Jakarta, Kalimantan Timur, dan Sulawesi Selatan. Dalam hal ini, Banten akan ditempatkan di peringkat kedua, bersama-sama dengan Jawa Tengah dan Kalimantan Barat.

Untuk mengatasi masalah subjektivitas, analisis sensitivitas dilakukan setelah model kasus dasar dijalankan. Input data aplikasi yang berasal dari estimasi bisa jadi lebih atau kurang dapat diandalkan. Sumber umum ketidakpastian individu bisa datang dari ketidakpastian data serial, ketidakpastian tentang masa depan, sinergi dan keanehan dalam penafsiran informasi yang ambigu atau tidak lengkap (Achillas, dkk, 2010). Untuk tujuan analisis sensitivitas, nilai faktor bobot dan ambang batas telah dimodifikasi. Dua belas skenario dengan membedakan preferensi dan indiferen ambang sebesar 50\% (peningkatan dan penurunan) diperiksa. Untuk semua skenario, ternyata Provinsi Banten masih muncul sebagai solusi optimal dalam model. Akan tetapi, Banten juga disertai dengan lokasi lainnya, seperti Kalimantan Barat, Lampung, Jakarta, Sulawesi Selatan. Namun demikian, Banten selalu muncul di semua skenario sebagai pilihan terbaik untuk lokasi FPLE. Selain itu, untuk solusi optimal berikutnya (kedua dan ketiga), peringkat lokasi tidak signifikan dipengaruhi oleh modifikasi batas preferensi dan indiferen, yang menunjukkan kekokohan metodologi yang disajikan model ELECTRE III.

Selain skenario tersebut di atas dua belas skenario modifikasi ambang batas dilakukan. Analisis sensitivitas juga dilakukan dengan modifikasi faktor bobot kriteria sebesar 50\% (peningkatan dan penurunan) dengan tetap mempertahankan konstanta semua ambang yang dinilai dalam skenario kasus dasar. Kriteria yang dimodifikasi adalah "Penduduk lokal" $\left(\mathrm{c}_{2}\right)$, dengan tetap menjaga bobot lain di bagian yang sama dari modifikasi dalam kriteria bobot dimodifikasi (misalnya, ketika bobot faktor "Penduduk lokal" kriteria yang meningkat sebesar $10 \%$, kriteria lain akan mengalami penurunan sebesar $10 \%$ di setiap bagian yang sama). Sekali lagi, untuk semua skenario ini Provinsi Banten muncul lokasi yang optimal, meskipun lokasi lain juga disertai Banten sebagai 
lokasi yang optimal, seperti Kalimantan Barat, Lampung, Maluku, Maluku Utara, Papua. Hasil analisis sensitivitas ini dapat dilihat pada Tabel 3 Dengan demikian, dengan analisis sensitivitas ini, para pengambil keputusan dapat memberikan keyakinan tambahan untuk memilih lokasi Banten di mana FPLE perlu dikembangkan. Seperti disebutkan sebelumnya, Banten tidak menjadi pilihan terbaik untuk lokasi FPLE jika ambang veto dihilangkan.

Tabel 3. Analisis Sensitivitas model ELECTRE III untuk pemilihan lokasi FPLE

\begin{tabular}{|c|c|c|c|c|c|c|}
\hline \multirow{2}{*}{$\begin{array}{l}\text { Skenario } \\
\text { \Ranking }\end{array}$} & \multicolumn{3}{|c|}{ Ambang batas } & \multicolumn{3}{|c|}{ Bobot } \\
\hline & Pertama & Kedua & Ketiga & Pertama & Kedua & Ketiga \\
\hline $\begin{array}{l}\text { Kasus } \\
\text { dasar }\end{array}$ & Banten & $\begin{array}{l}\text { Jakarta, Maluku, Maluku } \\
\text { Utara, Papua }\end{array}$ & $\begin{array}{l}\text { Sulawesi Utara, Sulawesi } \\
\text { Selatan }\end{array}$ & Banten & $\begin{array}{l}\text { Jakarta, Maluku, } \\
\text { Maluku Utara, Papua }\end{array}$ & $\begin{array}{l}\text { Sulawesi Utara, } \\
\text { Sulawesi Selatan }\end{array}$ \\
\hline$+5 \%$ & Banten & $\begin{array}{l}\text { Jakarta, Maluku, Maluku } \\
\text { Utara, Papua }\end{array}$ & $\begin{array}{l}\text { Sulawesi Selatan, Jawa } \\
\text { Tengah, Sulawesi Utara }\end{array}$ & Banten & $\begin{array}{l}\text { Jakarta, Maluku, } \\
\text { Maluku Utara, Papua }\end{array}$ & $\begin{array}{l}\text { Jawa Tengah, Sulawesi } \\
\text { Utara, Sulawesi Selatan } \\
\text { Selatan }\end{array}$ \\
\hline$+10 \%$ & $\begin{array}{l}\text { Banten, } \\
\text { Kalimantan } \\
\text { Barat }\end{array}$ & $\begin{array}{l}\text { Jakarta, Sulawesi Selatan, } \\
\text { Maluku, Maluku Utara. } \\
\text { Papua }\end{array}$ & $\begin{array}{l}\text { Lampung, Jawa Tengah, } \\
\text { Sulawesi Utara }\end{array}$ & Banten & $\begin{array}{l}\text { Jakarta, Maluku, } \\
\text { Maluku Utara, Papua }\end{array}$ & $\begin{array}{l}\text { Jawa Tengah, Sulawesi } \\
\text { Utara, Sulawesi Selatan } \\
\text { Selatan }\end{array}$ \\
\hline$+20 \%$ & $\begin{array}{l}\text { Banten, } \\
\text { Kalimantan } \\
\text { Barat }\end{array}$ & $\begin{array}{l}\text { Jakarta, Sulawesi Selatan, } \\
\text { Maluku, Maluku Utara. } \\
\text { Papua }\end{array}$ & $\begin{array}{l}\text { Lampung, Jawa Tengah, } \\
\text { Sulawesi Utara }\end{array}$ & $\begin{array}{l}\text { Banten, } \\
\text { Kalimantan } \\
\text { Barat }\end{array}$ & $\begin{array}{l}\text { Jakarta, Maluku, } \\
\text { Maluku Utara, Papua }\end{array}$ & $\begin{array}{l}\text { Lampung, Jawa Tengah, } \\
\text { Nusa Tenggara Timur, } \\
\text { Papua Barat }\end{array}$ \\
\hline$+\mathbf{3 0} \%$ & $\begin{array}{l}\text { Banten, } \\
\text { Kalimantan } \\
\text { Barat }\end{array}$ & $\begin{array}{l}\text { Jakarta, Sulawesi Selatan, } \\
\text { Maluku, Maluku Utara. } \\
\text { Papua }\end{array}$ & $\begin{array}{l}\text { Lampung, Sulawesi Utara, } \\
\text { Sulawesi Tenggara }\end{array}$ & $\begin{array}{l}\text { Banten, } \\
\text { Kalimantan } \\
\text { Barat }\end{array}$ & $\begin{array}{l}\text { Jakarta, Sulawesi } \\
\text { Selatan, Maluku, } \\
\text { Papua }\end{array}$ & $\begin{array}{l}\text { Lampung, Jawa Barat, } \\
\text { Jawa Tengah, Nusa } \\
\text { Tenggara Timur, Papua } \\
\text { Barat }\end{array}$ \\
\hline$+40 \%$ & $\begin{array}{l}\text { Banten, } \\
\text { Kalimantan } \\
\text { Barat }\end{array}$ & $\begin{array}{l}\text { Jakarta, Sulawesi Selatan, } \\
\text { Maluku, Maluku Utara. } \\
\text { Papua }\end{array}$ & $\begin{array}{l}\text { Sumatera Utara, Lampung, } \\
\text { Nusa Tenggara Timur, } \\
\text { Sulawesi Utara, Sulawesi } \\
\text { Tenggara, Papua Barat }\end{array}$ & $\begin{array}{l}\text { Banten, } \\
\text { Kalimantan } \\
\text { Barat }\end{array}$ & $\begin{array}{l}\text { Jakarta, Sulawesi } \\
\text { Selatan, Maluku, } \\
\text { Papua }\end{array}$ & $\begin{array}{l}\text { Sumatera Utara, } \\
\text { Lampung, Jawa Tengah, } \\
\text { Nusa Tenggara Timur, } \\
\text { Papua Barat }\end{array}$ \\
\hline$+\mathbf{5 0 \%}$ & $\begin{array}{l}\text { Lampung, } \\
\text { Banten, } \\
\text { Kalimantan } \\
\text { Barat }\end{array}$ & $\begin{array}{l}\text { Jakarta, Sulawesi Selatan, } \\
\text { Maluku, Maluku Utara. } \\
\text { Papua }\end{array}$ & $\begin{array}{l}\text { Sumatera Utara, Sulawesi } \\
\text { Utara, Sulawesi Tenggara, } \\
\text { Papua Barat }\end{array}$ & $\begin{array}{l}\text { Banten, } \\
\text { Kalimantan } \\
\text { Barat }\end{array}$ & $\begin{array}{l}\text { Jakarta, Sulawesi } \\
\text { Selatan, Maluku, } \\
\text { Papua }\end{array}$ & $\begin{array}{l}\text { Sumatera Utara, } \\
\text { Lampung, Nusa } \\
\text { Tenggara Timur }\end{array}$ \\
\hline$-5 \%$ & Jakarta, Banten & $\begin{array}{l}\text { Lampung, Sulawesi } \\
\text { Selatan, Maluku, Maluku } \\
\text { Utara, Papua }\end{array}$ & $\begin{array}{l}\text { Jawa Tengah, Nusa } \\
\text { Tenggara Timur, } \\
\text { Kalimantan Barat, } \\
\text { Sulawesi Tenggara, Papua } \\
\text { Barat }\end{array}$ & Banten & $\begin{array}{l}\text { Jakarta, Maluku, } \\
\text { Maluku Utara, Papua }\end{array}$ & $\begin{array}{l}\text { Lampung, Sulawesi } \\
\text { Utara, Sulawesi Selatan }\end{array}$ \\
\hline$-10 \%$ & Jakarta, Banten & $\begin{array}{l}\text { Lampung, Sulawesi } \\
\text { Selatan, Maluku, Maluku } \\
\text { Utara, Papua }\end{array}$ & $\begin{array}{l}\text { Sumatera Utara, Jawa } \\
\text { Barat, Jawa Tengah, Nusa } \\
\text { Tenggara Timur, } \\
\text { Kalimantan Barat, } \\
\text { Sulawesi Utara }\end{array}$ & $\begin{array}{l}\text { Lampung, } \\
\text { Banten }\end{array}$ & $\begin{array}{l}\text { Jakarta, Kalimantan } \\
\text { Barat, Sulawesi } \\
\text { Selatan, Maluku, } \\
\text { Maluku Utara, Papua }\end{array}$ & $\begin{array}{l}\text { Sumatera Utara, Jawa } \\
\text { Barat, Jawa Tengah, } \\
\text { Nusa Tenggara Timur, } \\
\text { Sulawesi Utara, } \\
\text { Sulawesi Tenggara }\end{array}$ \\
\hline$-20 \%$ & Jakarta, Banten & $\begin{array}{l}\text { Lampung, Sulawesi } \\
\text { Selatan, Maluku, Maluku } \\
\text { Utara, Papua }\end{array}$ & $\begin{array}{l}\text { Sumatera Utara, Jawa } \\
\text { Barat, Jawa Tengah, Nusa } \\
\text { Tenggara Timur, } \\
\text { Kalimantan Barat, } \\
\text { Sulawesi Utara }\end{array}$ & $\begin{array}{l}\text { Lampung, } \\
\text { Banten, } \\
\text { Maluku, } \\
\text { Maluku } \\
\text { Utara, } \\
\text { Papua }\end{array}$ & $\begin{array}{l}\text { Jakarta, Kalimantan } \\
\text { Barat, Sulawesi } \\
\text { Utara, Sulawesi } \\
\text { Selatan }\end{array}$ & $\begin{array}{l}\text { Sumatera Utara, Nusa } \\
\text { Tenggara Timur, } \\
\text { Sulawesi Tenggara } \\
\text { Tenggara, Papua Barat }\end{array}$ \\
\hline$-30 \%$ & $\begin{array}{l}\text { Lampung, } \\
\text { Jakarta, } \\
\text { Banten, } \\
\text { Sulawesi } \\
\text { Selatan }\end{array}$ & $\begin{array}{l}\text { Jawa Barat, Kalimantan } \\
\text { Barat, Maluku, Maluku } \\
\text { Utara, Papua }\end{array}$ & $\begin{array}{l}\text { Sumatera Utara, Jawa } \\
\text { Tengah, Sulawesi Utara, } \\
\text { Sulawesi Tenggara }\end{array}$ & $\begin{array}{l}\text { Lampung, } \\
\text { Banten, } \\
\text { Maluku, } \\
\text { Maluku } \\
\text { Utara, } \\
\text { Papua }\end{array}$ & $\begin{array}{l}\text { Jakarta, Kalimantan } \\
\text { Barat, Sulawesi } \\
\text { Utara, Sulawesi } \\
\text { Selatan }\end{array}$ & $\begin{array}{l}\text { Sumatera Utara, Nusa } \\
\text { Tenggara Timur, } \\
\text { Sulawesi Tenggara, } \\
\text { Papua Barat }\end{array}$ \\
\hline$-40 \%$ & $\begin{array}{l}\text { Lampung, } \\
\text { Jakarta, } \\
\text { Banten, } \\
\text { Sulawesi } \\
\text { Selatan }\end{array}$ & $\begin{array}{l}\text { Jawa Barat, Nusa Tenggara } \\
\text { Timur, Kalimantan Barat, } \\
\text { Maluku, Maluku Utara, } \\
\text { Papua }\end{array}$ & $\begin{array}{l}\text { Sumatera Utara, Jawa } \\
\text { Tengah, Sulawesi Utara, } \\
\text { Sulawesi Tenggara }\end{array}$ & Banten & $\begin{array}{l}\text { Lampung, Jakarta, } \\
\text { South Sulawesi, } \\
\text { Maluku, Maluku } \\
\text { Utara, Papua }\end{array}$ & $\begin{array}{l}\text { Sumatera Utara, Jawa } \\
\text { Tengah, Nusa Tenggara } \\
\text { Timur, Kalimantan } \\
\text { Barat, Sulawesi } \\
\text { Tenggara, Papua Barat }\end{array}$ \\
\hline
\end{tabular}




\begin{tabular}{|c|c|c|c|c|c|c|}
\hline \multirow{2}{*}{$\begin{array}{r}\text { Skenario } \\
\text { \Ranking }\end{array}$} & \multicolumn{3}{|c|}{ Ambang batas } & \multicolumn{3}{|c|}{ Bobot } \\
\hline & Pertama & Kedua & Ketiga & Pertama & Kedua & Ketiga \\
\hline$-50 \%$ & $\begin{array}{l}\text { Lampung, } \\
\text { Jakarta, } \\
\text { Banten, } \\
\text { Sulawesi } \\
\text { Selatan }\end{array}$ & $\begin{array}{l}\text { Jawa Barat, Kalimantan } \\
\text { Barat, Maluku, Maluku } \\
\text { Utara, Papua }\end{array}$ & $\begin{array}{l}\text { Sumatera Utara, Jawa } \\
\text { Tengah, Kalimantan Timur, } \\
\text { Sulawesi Utara, Sulawesi } \\
\text { Tenggara }\end{array}$ & $\begin{array}{l}\text { Banten, } \\
\text { Kalimantan } \\
\text { Timur }\end{array}$ & $\begin{array}{l}\text { Lampung, Sulawesi } \\
\text { Selatan, Maluku, } \\
\text { Maluku Utara, Papua }\end{array}$ & $\begin{array}{l}\text { Jakarta, Kalimantan } \\
\text { Barat, Papua Barat }\end{array}$ \\
\hline
\end{tabular}

\section{Kesimpulan}

Berdasarkan model yang digunakan dalam penelitian ini, Provinsi Banten merupakan lokasi yang paling optimal untuk mengembangkan fasilitas pengolahan limbah elektronik di Indonesia.

\section{Daftar Pustaka}

Achillas, C., Vlachokostas, C., Moussiopoulos, N., Banias, G.,2010. Decision support system for the optimal location of electrical and electronic waste treatment plants: A case study in Greece. Waste Management 30, 870879.

Andarani, P. and Goto, N., 2012. Preliminary Assessment of Economic Feasibility for Establishing Dismantling and Sorting Facility of Household's E-waste in Serang, Indonesia. Proceedings of Annual Meeting of Environmental Science Association 2012, p. 56.
ASEM (Asia-Europe Meeting), 2009. Information on Indonesia. ASEM Development Conference II: Toward An Asia-Europe Partnership for Sustainable Development. May 26-27, 2010, Yogyakarta, Indonesia

BPS, Statistical Center of Bureau, 2010. Statistical Pocketbook of Indonesia. BPS, Indonesia.

Buchanan, J., Sheppard, P., Vanderpooten, D., 1999. Project Ranking using ELECTRE III.

CEIC, 2011. Latest actual data: 2010. CIA, 2009. The World Factbook 2009. Washington, DC: Central Intelligence Agency.

Laboratoire d'Analyse et Modelisation de Systemes pour l'Aide a la decision (LAMSADE), 2009. ELECTRE III-IV Software Official Webpage.

Widyarsana, I. M. (2011) Studi Kasus Kota Bandung) "Tantangan dan Strategi Pengelolaan Limbah Elektronik (E-Waste) di Indonesia". Disertasi Doktor. Institut Teknologi Bandung. 